\title{
Policy on Rice Storage of Vietnam in International Economic Integration: Arising Problems
}

\author{
VŨ VĂN HÙNG \\ Commercial University - hungvvu@vcu.edu.vn
}

\begin{abstract}
ARTICLE INFO
ABSTRACT

Article history:

Received:

July 15, 2013

Received in revised form

Aug. 5, 2013

Accepted:

March 31, 2014

The article is written while Vietnam's export of rice is facing various difficulties and falls in the rice price, producing a strong impact on the lives of the millions of Vietnamese farmers. Since 2006 , in order to maintain a stable living for Vietnamese rice producers when the rice price falls sharply after harvest, the Government has implemented the policy on purchasing rice for storage twice a year to ensure rice producers get $30 \%$ profit at least. The article analyzes the policy on storage of rice, concentrating on the implementation process. Qualitative analysis method is used to assess the implementation of this policy in various aspects such as appropriateness, effectiveness,

Keywords:

policy, rice producer, rice storage; rice export. fairness and compatibility. The results allow authors to offer some recommendations that can serve as a basis for improvements in the implementation of this policy.
\end{abstract}




\section{POLICY ON RICE STORAGE OF VIETNAM IN INTERNATIONAL ECONOMIC INTEGRATION}

\section{a. Policy on Rice Storage:}

The word "policy" refers to any intervention by the government into an industry, a field or the whole economy to achieve a particular target by particular tools and measures for a definite time. Economic policies aim at influencing some sectors or components, such as manufacturing, agriculture, service, production, and consumption, etc.

Policies on agriculture and rural development include economic measures and the others taken by the government to affect agricultural and rural sectors and related ones.

Agriculture and rural development comprises a system of industries and fields with characteristics in their activities, which requires policies different from those on other sectors and industries. Depending on its planned targets, government takes measures to influence production, consumption, and distribution in this sector, or ensure some social target or equal division in the value chain.

This policy involves all tools and measures taken by the government to raise the rice price and ensure a minimum profit of $30 \%$ for the farmers every two or three months and twice a year.

This policy has been implemented for many years, especially after Vietnam's accession to the WTO in 2007 and commitment to open the market for farm products, reduce tariffs, and support to local farm products in general and rice in particular.

\section{b. Necessity of the Policy on Rice Storage:}

The policy on purchasing rice for storage affects greatly consumption of rice because:

First, consumption is not only an important component of entire remanufacturing process but an indispensable link in a distribution system that connects producers and consumers, thereby supporting production, economic growth, and bringing benefits to producers and consumers. Rice farming is a traditional and important industry, and its development plays a decisive role in stability of a large sector, as well as ensures the harmonic relationship between agriculture, farmers and rural development. Thus, it is crucial to improve the policy on rice storage in order to ensure rice producers' benefits.

Second, a policy to support rice consumption is actually essential because rice farming suffers more difficulties than other sectors and industries. Playing an important role in agriculture, rice production much depends on natural conditions; therefore, this 
sector is energy-consuming, less profitable, and vulnerable to risks in both production and markets. The biggest risk facing rice producers is the commodity-market risk, which requires support from the government and makes policy on rice storage truly important.

Third, Vietnam has integrated more fully into world economy, so its policies must ensure a balance between trade liberalization and protectionism. The policy on rice storage is also required to ensure the harmony of increases in export turnover, interests for rice producers and government, and international commitments. Thus, it is crucial to implement effectively a policy on rice storage during the international economic integration.

Fourth, rice farmers in Vietnam often worry about shortage of food after poor harvests and price falls after good ones. They can control their farming land and process of cultivation, but sale and distribution of rice are beyond their reach because rice, like other products, are affected greatly by market rules. Farmers have no facilities for storing rice after harvest, and they have to sell their output to cover production cost. As a result, they usually suffer losses because of price fluctuations. Therefore, the government is right to adopt a policy on rice storage to support rice producers during the present economic integration.

\section{c. Theoretical Bases and Criteria for Evaluating the Policy:}

- Bases for identifying evaluation criteria:

Vilfredo Pareto introduced the concept of "Pareto efficiency" when studying economic efficiency and income distribution. Given a group of individuals and various allocations of resources to each individual, a change to a different allocation that makes at least one individual better off without making any other individual worse off is called Pareto improvement or Pareto optimality. An allocation is called "Pareto efficient" or "Pareto optimal" when no further Pareto improvements are made. Thus, Pareto efficiency is considered as an important criterion for evaluation of economic systems and policies.

According to Kaldor-Hicks efficiency, an allocation of resources may increase benefits for one individual and reduce those for another provided that total benefit is a positive value when, theoretically, gains for those who are made better off can compensate for losses suffered by those who are made worse off.

At the annual agricultural outlook conference held in April, 2013 in Hà Nội, Trần Hoàng Nhị (Centre of Policy Analysis of Monash University, Australia) presented a trial 
model in which he indicated that exported rice prices can increase by $3.9 \%$ and profit for Mekong Delta farmers rise by $2.4 \%$ if government stops implementing the policy on the rice storage. When this policy is made and implemented, many businesses often cut rice purchasing prices as good harvests are in sight, and VFA (Vietnam Food Association) and the Ministry of Agriculture and Rural Development start asking the government for huge loans for procurement of rice for storage. However, businesses still have to purchase rice from farmers to fill orders placed by foreign buyers if this policy is revoked. According to many experts, in addition, the government should purchase farmers' rice with public fund and keep it in the national reserve system instead of allowing businesses to control this task. This method can reduce the tension between demand and supply. After that, reserved rice could be sold by auctions to rice exporting companies at suitable times.

Cao Đức Phát, Minister of Agriculture and Rural Development, stated that the policy on rice storage is only a temporary solution suggested by VFA and the MARD to deal with difficulties in rice consumption and falling rice prices. In the long term, however, several combined policies are much needed, such as adjusting the area of the third crop, keeping from $20 \%$ to $30 \%$ of the crop output in the national reserve system, $20 \%-30 \%$ in VFA silos and 10\%-20\% in farmers' barns, and allowing the rest to be traded to reduce the volume of unsaleable rice.

In theory, therefore, economists such as Pareto, Kaldor and Hicks evaluate socioeconomic policies in two aspects: efficiency and fairness. In reality, however, experts, as stated above, confirm that Vietnam's policy on rice storage is not suitable, or in need of changes and supplements.

- Criteria for Evaluating the Rice Storage Policy:

There are many criteria for evaluating this policy. This paper suggests four criteria: appropriateness, effectiveness, fairness, and compatibility as presented in Table 1. 
Table 1: Evaluation Criteria of Rice Storage Policy

\begin{tabular}{ll}
\hline \multicolumn{1}{c}{ Criteria } & \multicolumn{1}{c}{ Contents } \\
\hline \multirow{2}{*}{ Appropriateness } & $\begin{array}{l}\text { Is the policy appropriate to available resources? Who will it serve? Is it } \\
\text { compliant with Vietnam's commitment as a member to international economic } \\
\text { organizations? Is there any conflict between the policy and such commitments? }\end{array}$ \\
& $\begin{array}{l}\text { How much does the policy cost and how much benefit does it bring about? What } \\
\text { Effectiveness }\end{array}$ \\
& $\begin{array}{l}\text { is the benefit-cost ratio? Does benefit match resources spent on implementation } \\
\text { of the policy? }\end{array}$ \\
& $\begin{array}{l}\text { Are benefit and cost distributed equally among all communities? How much } \\
\text { increased benefit may rice producers receive? }\end{array}$ \\
Compatibility & $\begin{array}{l}\text { Does the policy on rice storage conflict with others on agriculture and the whole } \\
\text { economy? To what extent is this policy related to others and what should be } \\
\text { done to make the policy achieve intended results? }\end{array}$
\end{tabular}

Source: Vũ (2013), p. 57.

In short, evaluating the policy on rice storage aims at assessing whether this policy achieves its planned targets, serves the right beneficiaries, and improves the position of the nation and its farmers in the world rice market. Thus, the policy should be feasible and effective. Its implementation should be monitored and adjusted to the domestic market conditions and stronger and faster upheavals in the world market when Vietnam has to carry out its commitments to the WTO.

\section{EVALUATION OF POLICY ON RICE STORAGE OF VIETNAM IN INTERNATIONAL ECONOMIC INTEGRATION}

\section{a. Appropriateness:}

In line with the whole economy, Vietnam's agriculture and rice are integrating more fully into world market, and Vietnam has to ensure that policies on farm products market and rice storage is totally compliant with its commitments to the WTO. Yet, the implementation of this policy reveals many inadequacies, such as:

- This policy should be oriented toward Vietnam's advantages and conditions as one of leading exporter of rice that is affected by both domestic and international markets. Vietnam fails to closely follow fluctuations in international rice market, thereby adjusting the policy to promote export volume timely. In the last five years, rises in 
volume of exported rice usually took place when the rice price fell to the lowest level, and vice versa.

- In managing the rice export, the government should closely watch the fluctuations in the world rice market and make accurate and regular predictions in order to take the most optimal measures to earn the possibly highest profits. In 2008, for example, the government stopped rice exports to ensure food security because of incorrect predictions about rice supply and demand in the world market. After the first quarter of 2008, the rice price skyrocketed. By the end of 2008 the price fell when the volume of rice in storage was huge. Such wrong decisions really produce bad effects on farmers' life.

- The price floor set for exported rice is also one of the most important problems. In spite of decreasing competition from Thailand, Vietnam still faces other rivals such as India and the Philippines in the segment of low-quality rice. Meanwhile, rice exporters cannot reduce prices to win more market share because of the price floor. Thus, the price floor should be adjusted flexibly to maximize profits for rice exporters and producers when they take part in the world rice market.

- Allocation of quota of rice storage to purchasing companies is not rational because of differences in rice growing areas and output among Mekong Delta provinces. Cần Tho province, for example, is granted a quota of 131,000 tonnes of rice for storage although its rice planting area is not large while Kiên Giang, the biggest producer in terms of area and output, is only allowed to store 85,000 tonnes.

- The timing of rice storage is not really appropriate because of differences in harvest time among Mekong Delta provinces, which leads to unruly purchase of rice and unnecessary competition among rice trading companies and failure to keep the rice price at a high level.

\section{b. Effectiveness:}

- According to SBV reports, total loan used for purchasing a million tonnes of rice for storage in the 2013 winter-spring crop in the Mekong Delta reached VND7,612 billion. With a subsidized interest rate of $11 \%$ a year and a time to maturity of three months, the government had to pay roughly VND209 billion to rice purchasing companies in this season. If the rice price rises by VND150 per kilogram, the extra proceeds from sale of the million tonnes of rice will be VND150 billion, which is still lower than the subsidy for rice storage. This situation shows that this policy is still only a nominal support because benefit for farmers is small, rice purchasing companies report 
losses, and a large sum from public fund is wasted. These facts imply that the implementation of this policy fails to produce good results in terms of costs-benefit relationship and cannot compensate for resources (time, energy and money) invested in this policy.

- Exporting from five to seven million tones of rice every year, Vietnam sells most of its rice storage to foreign markets. From early 2013 onward, however, Vietnamese rice export has met with difficulties, and VFA had to cut export price to retain its market shares. Loss of traditional markets to rivals, increasing dependence on the Chinese market and poor ability to seek for and negotiate with new buyers prevent Vietnam from exporting the volume of rice in stock. In such a situation, rice trading companies are reluctant to purchase rice even if they are provided with interest-free loans because they cannot find export markets, which indicates that effectiveness of the policy is low. In addition, fluctuations in the world market also make rice prices fall, and a $30 \%$ profit for rice producers cannot be ensured.

\section{c. Fairness:}

- The policy on rice storage is not oriented toward rice producers as its main beneficiaries. In reality, when rice price increases, VFA promotes rice purchase through companies provided with quotas; and when the price falls, VFA burdens local governments with the task of purchasing rice for storage. This practice does not bring any benefits for farmers, and moreover, it reduces their role because they cannot decide at what price and when they can sell their produce and have to depend on many rules, mechanisms and authorities, which indicates that this policy does not ensure fairness.

Rice producers, according to the $\mathrm{WB}$, still belong to one of the poorest groups. In Vietnam, farmers only receive from $30 \%$ to $33 \%$ of added value of rice and undertake over $50 \%$ of workload whereas rice trading companies gain $67 \%$ of added value and do only $10 \%$ of the workload.

- The distribution of benefits among participants in the value chain of rice also damages the fairness in which farmers always suffer losses. Most producers of rice for export, especially those in the Mekong Delta, usually cultivate in large areas, make huge investment in their businesses and have no facilities for storing large quantities of rice after harvest. They have to sell their crop to cover costs and repay loans, meanwhile, businesses can take time to purchase rice for storage because they have one to two months for this task. This situation reveals a contradiction between farmers' need to sell 
rice as soon as possible and trading companies' rights to delay purchase. Farmers always suffer losses caused by this market risk.

Under unfavorable market conditions, rice trading companies may start purchasing in the last days of the time set for this task when subsidized bank loans for them are still valid. They have right to decide the purchasing time to maximize their profit based on fluctuations in the world market. Thus, farmers are the most vulnerable party in the process of international integration of Vietnamese economy and the rice business as well.

- Last but not least, the given problem here is the existence of traders, especially the Chinese ones, who work around the Mekong Delta during harvest time. These traders gain a significant share in the rice value chain by taking advantage of farmers' need to sell rice to force them to cut selling price and reselling it to rice export companies at a much higher price. This group also breaks the connection between farmers and rice trading companies, lowers profit in the value chain, and prevents the policy on rice storage from ensuring a $30 \%$ profit for farmers and an equal distribution of benefits among participants in the chain.

\section{d. Compatibility:}

The terminology implies that a policy should be in harmony with others. Otherwise, it cannot produce any results. The policy on rice storage has direct relations with a series of other policies. Its implementation causes many problems:

- The subsidized loans are available for rice trading companies within three months while purchasing time may last from one to two months. These companies only start purchasing in the last weeks of this period when imbalance between supply of and demand for rice decreases the price sharply. In such a situation, rice producers suffer all losses while benefits for these companies in terms of subsidized loans remain intact.

- The government is now encouraging formation of large model field, but this program is not closely linked with the policy on rice storage. If priority is given to this program, it will be more convenient for participant farmers who can supply rice in large quantities because they engage in a closed process from sowing to harvesting on large fields.

- Cooperation among four relevant parties - local authorities, farmers, scientists and businesspersons in the rice storage program is not effective enough. Authorities do not master their coordinating role in cooperation models, state-owned rice trading 
companies fail to win trust from farmers because private traders ruin the connection between farmers and businesses. Scientists fail to develop new rice strains that could be exported at high prices because, after all, the rice storage should be closely linked with export. In other words, this program is meaningless if export of rice falls. Thus, many factors play extremely important roles in the success of the policy on rice storage, such as management of rice export, timing of rice export, decisions on the floor of rice price, promotion of trade in rice, and building of brand names for Vietnamese rise, etc.

\section{SOME RECOMMENDATIONS FOR IMPROVEMENT IN THE RICE STORAGE POLICY}

\section{a. Improvement in Appropriateness:}

- Export management and floor price: The Ministry of Industry and Trade (MIT) can set the floor for export rice to deal with falls in rice output and export value. How to set a price floor for exported rice that ensures competitiveness as well as stability of rice purchasing price in the domestic market is an urgent issue. Thus, the Ministry should cooperate with relevant ministries and agencies to manage the price floor in the most flexible and timely manner. From February to April 2012, for example, VFA had to reduce the price floor twice due to the continuously falls in rice prices on the world market (from US $\$ 520$ to 480 per ton for the 5\% broken rice and from US $\$ 490$ to 460 per ton for the $25 \%$ broken rice). This fact reflects flexible management of price floor of rice for export by authorities to ensure all targets of government's intervention.

- Distribution of quotas of rice purchased for storage could be assigned to local governments in which quotas assigned by MIT and VFA will be divided among rice trading companies, including VFA-controlled ones, doing business in the province based on their storing facilities. Assignment of quotas should be based on rice output and storing facilities in the province. Kiên Giang Province, for example, could be granted a quota larger than that for Cần Thơ and HCMC because it is the largest granary in the Mekong Delta.

- Time and duration set for purchasing rice of winter-spring crop should be started and finished earlier and companies should complete their purchases in March. If the purchase lasts till April or May, this program will be inappropriate because the harvest of summer-autumn crop comes in June and July. This situation may affect badly the rice purchase of summer-autumn rice because of large quantities of winter-spring rice are still held by farmers. 


\section{b. Improvement in Effectiveness:}

- To purchase rice for storage more effectively, companies should separate purchase subsidized by the government from their annual purchasing plans, thereby making farmers real beneficiaries of this program.

- Government should adopt a new policy appropriate to specific conditions of each region. In the Mekong Delta in particular, beneficiaries of this program are rice producers and companies having purchasing agreements. Sellers include farmers, cooperatives, mutual supporting groups of farmers, and rice producing concerns (stateowned farms and companies cooperating with farmers to grow rice on large model fields). Farmers can sell their winter-spring output to this program in February, March and April, and summer-autumn output in July, August, and September.

Concerning rice trading companies, they should purchase rice when the market price falls under a level where a $30 \%$ profit for farmers cannot be ensured, or when rice sale is difficult and the volume of rice in stock is too large. Supply of supporting loans to farmers and companies is based on the volume of rice purchased for storage and unit price set by the Ministry of Finance for each crop harvest and province. The government will pay interest on these loans for farmers and companies within 3 months at most.

- Time to receive subsidized loans should be set from the day that rice is put in storage to the day that rice is sold according to receipts signed by the organizations or individuals who grant documents about rice storage. This new mechanism for the rice storage can allow farmers to receive subsidized loans from the government to prepare next crops when falls in market price after harvest prevent them from selling their rice output from the last crop at reasonable prices. Rice production is seasonal and farmers must cover various expenditures. They therefore want to obtain cash right after harvest. The rice price, however, tends to fall after harvest time when the supply exceeds the demand; hence, new regulations on the time to receive subsidized loans from the government will help solve this problem for farmers.

\section{c. Improvement in Fairness:}

The policy on rice storage impacts on many involved parties so their interests should be ensured harmoniously, but top priority should be given to farmers' interest. Hence, it is necessary to have consistent measures to increase benefits for farmers when Vietnam's rice production integrates into the world market. 
- The most important problem to deal with is the rice export, or in other words, finding the export markets and buyers because difficulties in export (as from early 2013 to early 2014) may lead to various problems: (1) Companies refuse to purchase rice for storage during the harvest time because they have no export contract, which allows private traders to force farmers to cut their selling price; (2) Farmers cannot but sell their rice output as soon as possible because they have to repay loans while lacking facilities for storage; and (3) Companies can purchase whenever they want because the time to receive subsidized loans is long.

In brief, the main cause of these problems is the lack of export markets, which makes farmers suffer the greatest losses while traders and rice trading companies are almost not affected. Thus, we can see that farmers only gain a small value from the chain under good market conditions, in contrast, when conditions are not good, they face the biggest disadvantages: have no facility for storage and no good buyers for their rice. To deal with this difficulty, the government should expand and maintain export markets and help farmers change their crops.

- Vested interest of rice trading companies should be solved completely. VFA is responsible for assigning quotas of rice purchased, but its management is poor and it has no ability to monitor implementation of the program by companies and evaluate their actual competence because in reality, several companies cannot achieve any assigned targets after gaining quotas. Thus, the government should require provincial governments to solve these problems by determining the volume of rice to keep in stock and the period of time for rice purchasing program based on local rice output and harvest time. This practice can avoid differences between output and quotas of rice for storage assigned to provincial governments, or failure to purchase rice right after the harvest time because the province has to wait for quotas from central authorities.

- Local governments should monitor more closely the purchase of rice by private traders, especially Chinese ones, and activities of middle persons between farmers and private traders. This supervision can help farmers gain higher values from the global value chain of rice, thereby ensuring the fairness in distribution of benefits among rice producers and traders.

\section{d. Improvement in Compatibility:}

- All stages of the policy implementation should be consistent and under close supervision and control. To prevent the lateness of rice purchase that leads to too huge 
volume of rice accumulated in households at the peak of harvest time and sharply falls in rice prices, the central government, besides supplying subsidized loans, should closely supervise the policy implementation and directly take part in the rice storage program to adjust and implement the policy consistently.

- The government should introduce policies and measures to link various programs (such as the ones to build large model fields, restructure agricultural production and alter structure of rice output, modernize rural areas, and link four parties in agricultural development) with the rice purchase for storage. This connection will create a closed system of various policies that aim at serving farmers who are the most vulnerable in the integration into the world economy. Vietnamese rice is exported to markets all over the world, but the benefit from the value chain of rice for farmers has gradually decreased, which makes Vietnam's position as the world's leading exporter of rice meaningless.

- Enhance proactive and autonomous spirits of companies and adjustment by the government: rice storage is just a temporary measure when the supply exceeds the demand in a short term, but it is almost ineffective when rice export cannot be promoted. The purchase of rice of summer-autumn crop of 2013 is an example of this situation when the purchasing price was very low, from VND3,500 to 4,000 per kilo while it requires a price of VND5,300 at least to ensure a 30\% profit for farmers. Thus, the government should offer incentives to attract major partners and intergovernmental contracts for rice trading. Particularly, a long term publicity strategy to enhance the image of Vietnamese rice should be launched to ensure that in the future the quality of Vietnamese rice will not be underestimated as at the present.

- Policies on relevant fields should be made to reduce the pressure of rice supply when market conditions are not favorable or rice supplies in the world market increase, such as: using the rice as raw materials for animal husbandry, sea farming, or food processing industries; or developing new products made from rice to reduce the volume of rice waiting for export under bad market conditions.

\section{CONCLUSION}

Through the analysis of the theoretical framework and examination of problems with the policy on rice storage, the author finds that the policy produces few positive consequences while creates various problems. The implementation of this policy reveals four major inadequacies: (1) the policy is not appropriate to reality; (2) the policy is not as effective as expected; (3) fairness in distribution of benefits among relevant parties is 
not ensured; and (4) the policy is not compatible with other policies on agriculture and rural development. Such inadequacies become more serious when Vietnam's export market contracts. The key solution to the problem is the export business: when export of rice rises, farmer's living standard may be improved. If Vietnam wants to become one of the world's largest rice exporters and helps farmers to prosper by growing rice, the policy on rice storage in the coming years should be placed in a close relationship with the integration into the international economy

\section{References}

Chu Khôi (2013), “Tạm trữ lúa gạo: Cần định lượng hiệu quả” available at http://www.kinhtenongthon.com.vn/Story/VandeSukien/2013/6/41755.html, retrieved on Jan. 8, 2014

IPSARD (2006), “Từ điển kinh tế nông nghiệp nông thôn”, entry "Kaldor-Hicks efficiency”, available at http://ipsard.gov.vn/news/dict.asp?word=Kaldor-Hicks efficiency\&letter=K\&LOAI_TU_DIEN=ANH-VIET\&pNum=1, retrieved on Jan. 12, 2014

Lê Nguyễn (2013), "Sẽ không để nông dân chịu lỗ", available at http://citinews.net/kinh-doanh/-sekhong-de-nong-dan-chiu-lo--LSHNOIA/ retrieved on Jan 12, 2014

Phạm Văn Khôi (2007), Giáo trình phân tích chính sách nông nghiệp, nông thôn, Đại học Kinh tế Quốc dân Publisher.

Thông tấn xã Việt ban (2013), "Tăng thời hạn mua tạm trữ thóc và gạo vụ hè thu”, available at http://www.vietnamplus.vn/Home/Tang-thoi-han-mua-tam-tru-thoc-va-gao-vu-He-

Thu/20137/209337.vnplus, retrieved on Jan. 12, 2014

Việt Tiến (2013), "Nỗi lo được mùa rớt giá nơi vựa lúa", Nhân dân, No 21097 dated June 20, p. 5.

Vũ Văn Hùng (2011), "Quan điểm về nâng cao hiệu quả liên kết bốn "nhà”: Nhà nước, nhà nông, nhà khoa học và nhà doanh nghiệp”, Kinh tế châu Á - Thái Bình Dưong, (347), pp. 40-42.

Vũ Văn Hùng \& Phạm Văn Dũng (2012), "Xuất khẩu gạo của VN sau 5 năm gia nhập WTO: Thực trạng và giải pháp”, Kinh tế châu Á - Thái Bình Dưong, (367), pp. 28-32.

Vũ Văn Hùng (2013), "Chính sách tiêu thụ nông sản Việt Nam trong quá trình thực hiện các cam kết với Tổ chức thương mại thế giới”, doctoral dissertation, at VNU University of Economics and Bussiness, p. 57.

Wikipedia (2013), "Hiệu quả Pareto" available at https://vi.wikipedia.org/wiki/Hi\%E1\%BB\%87u_qu\%E1\%BA\%A3_Pareto, retrieved on Jan. 10, 2013 